\title{
Seppo Niemelä in memoriam
}

$\mathcal{E}$ lokuun sunnuntaina 2.8.2015 kuoli kansalaisvaikuttamisen ja vapaan sivistystyön, aikuiskasvatuksen ja sosiaalipedagogiikan tärkeä vaikuttaja, lehtimies ja tietokirjailija FT Seppo Niemelä. Seppo Niemelän persoona ei jättänyt ketään kylmäksi. Hänen vahva ja juureva elämänotteensa ja elämäntyönsä on jättänyt syvän jäljen suomalaisen sivistys-ja kulttuurityön ehtoihin ja edellytyksiin.

Niemelä oli vahvasti mukana kansalaisvaikuttamisen politiikkaohjelman vetäjänä, Yleisradion hallintoneuvoston jäsenenä ja puheenjohtajana ja monissa luottamustehtävissä, esimerkiksi Aikuiskasvatus-lehden toimituskunnan jäsenenä. Sanomalehtimiehenä hän toimi muun muassa Suomenmaan päätoimittajana.

Niemelä oli koko elämänsä virkeä ja uusia ideoita tuoreella tavalla generoiva henkilö, jonka luomat uudet teoreettiset käsitteet, kuten opinnollinen kuntoutus, ohjasivat vapaan sivistystyön käytäntöjä myös toiminnan tasolla. Vapaan Sivistystyön Yhteisjärjestön pääsihteerinä ja aikuiskasvatuksen ja kansalaisvaikuttamisen tutkijana Niemelä oli huolestunut sosiaalisen katoamisesta oppimisesta ja vapaasta sivistystyöstä. Hän oli huolestunut yhteistyön ja yhteisöllisyyden rakenteiden romuttumisesta suomalaisessa yhteiskunnassa laajemmin ja puolsi esimerkiksi ajatusta, että "kunnan tulee olla ihmiselle käsitettävän kokoinen”. Viime vuosina hän oli myös ideoimassa ja tukemassa perhekansanopiston idean kehittelyä vapaassa sivistystyössä. Hän oli myös erittäin huolestunut siitä, mitä tapahtuu suomalaisen yliopistolaitoksen sivistystehtävälle. Hänen mukaansa yliopistoissa "jyrää" nykyään pelkästään talous, ja yliopistot ovat unohtaneet kansallisen sivistystehtävänsä. Yliopistot ovat sortuneet matkimaan "huippuun viritettyjä teollisia prosesseja".

Seppo Niemelä kokosi elämäntyönsä väittelemällä sosiaalipedagogiikasta aiheenaan Sivistyminen.
Sivistystarve, -pedagogiikka ja -politiikka pohjoismaisessa kansansivistystraditiossa (2011). Myöhemmin hän aktiivisena verkkokirjoittelijana kertoi, että asia, joka häntä edelleen eniten innostaa ja kiinnostaa, on juuri eri elämänvaiheissa olevien ihmisten kasvun ja sivistyksen prosessit ja niiden tukeminen.

Innostavana puhujana ja kirjoittajana hän halusi herättää ja auttaa kuulijoitaan ja lukijoitaan löytämään omassa elämässään kunkin ainutkertaisen ja omaehtoisen toimintakyvyn, potentiaalit ja luovuuden, mikä voi johtaa "oman jutun" löytymiseen. Niemelä toimi elämässään eräänlaisena sosiaalisena ja kulttuurisena innostajana. Useissa yhteyksissä hän kannusti opiskelijoita löytämään oman tiensä. Tähän kasvuun tarvitaan elävää vuorovaikutusta ja sosiaalisuutta. Luennoissaan ja kirjoituksissaan hän oli kiinnostunut sellaisesta sivistyspedagogiikasta, joka mahdollistaa yksilölle kokemuksen oman elämänsä arvokkuudesta ja elämän merkityksellisyydestä.

Kansalaisvaikuttamisen, vapaan sivistystyön, aikuiskasvatuksen ja sosiaalipedagogiikan tärkeänä ja keskeisenä vaikuttajana Seppo Niemelä on jättänyt merkittävän vaikutuksen suomalaiseen kulttuuriin, yhteiskuntaan ja erityisesti henkilöihin, joilla oli ilo saada tuntea hänet henkilökohtaisesti. Hänen voimakas viestinsä suomalaisen yhteiskunnan ja yliopistojen tilasta herättää meitä yhä: "sivistys korahtelee tällä hetkellä henkitoreissaan".

Tämä viesti kannustaa ja myös velvoittaa meitä jatkamaan Seppo Niemelän työtä sivistysyliopiston, vapaan sivistystyön, ihmisarvoisen ja rikkaan elämän ja kulttuurin puolustamiseksi.

Karin Filander

Esihenkilö, pj.

Aikuiskasvatuksen Tutkimusseura

Tampereen yliopiston kasvatustieteiden yksikkö 